\title{
A secondary metabolite, 4,5-dibromopyrrole-2-carboxylic acid, from marine sponges of the genus Agelas alters cellular calcium signals
}

\author{
Ulf Bickmeyer ${ }^{\mathrm{a}, *}$, Michael Assmann ${ }^{\mathrm{b}}$, Matthias Köck ${ }^{\mathrm{b}}$, Christian Schütt ${ }^{\mathrm{a}}$ \\ a Alfred-Wegener-Institut für Polar- und Meeresforschung in der Helmholtz-Gemeinschaft, Biologische Anstalt Helgoland, Kurpromenade, \\ D-27498 Helgoland, Germany \\ b Alfred-Wegener-Institut für Polar- und Meeresforschung in der Helmholtz-Gemeinschaft, Am Handelshafen 12, D-27570 Bremerhaven, Germany
}

Available online 2 February 2005

\begin{abstract}
A secondary metabolite from sponges of the genus Agelas, 4,5-dibromopyrrole-2-carboxylic acid, which is well known as feeding deterrent, was investigated for effects on the cellular calcium homeostasis in PC12 cells. 4,5-Dibromopyrrole-2-carboxylic acid did not change intracellular calcium levels if applied alone without cell depolarization. During depolarization of the cellular membrane using high potassium solution, a dose dependent reduction of intracellular calcium elevation was revealed utilizing Fura II as calcium indicator. Significant reduction was seen at concentrations higher than $30 \mu \mathrm{M}$ in a series of experiments, but in single experiments a concentration of $300 \mathrm{nM}$ was still reversible effective. In the same concentration range, the onset of depolarization induced calcium elevations was significantly delayed by 4,5-dibromopyrrole-2-carboxylic acid. Dose dependent reduction and delay of depolarization evoked calcium elevations are probably due to a reduction of calcium entry via voltage operated calcium channels. One cellular mode of action of the feeding deterrent potential of 4,5-dibromopyrrole-2-carboxylic acid to fishes may be an interaction with the cellular calcium homeostasis of exposed cells.

(C) 2005 Elsevier B.V. All rights reserved.
\end{abstract}

Keywords: Secondary metabolite; Sponge; Agelas; Calcium imaging; Fluorescence; Calcium entry

\section{Introduction}

Marine organisms represent an excellent source for bioactive compounds. Especially sponges are known to be a rich font for interesting secondary metabolites, for example the genus Agelas (Agelasidae) is well known to contain a variety of bromopyrrole alkaloids (reviewed in Braekman et al., 1992; Lindel et al., 2000). Recently, detailed studies have shown both at laboratory and field conditions, that brominated pyrrole alkaloids like 4,5-dibromopyrrole-2-carboxylic acid were the principal fish antifeedant metabolites within the sponge tissue of Agelas sponges at natural concentrations (Pawlik et al., 1995; Chanas et al., 1996; Assmann et al., 2000, 2004). However, the chemosensory and cellular mechanisms of brominated pyrrole alkaloids to function as a feeding deterrent are not investigated so far. Chemo-receptive cells are exposed to the environment and cellular signaling

\footnotetext{
* Corresponding author. Tel.: +49 4725819 224; fax: +49 4725819236.

E-mail address: ubickmeyer@awi-bremerhaven.de (U. Bickmeyer).
}

may be modulated by substances interacting with the basic physiology of the cell, not necessarily by binding to specific taste receptors. Therefore, we tested 4,5-dibromopyrrole-2carboxylic acid, a prominent secondary metabolite of Agelas sponges, for cell physiological effects in an established cell line. PC12 cells stem from a rat phaeochromocytoma of the adrenal gland. These cells can be differentiated into neuron-like cells and produce catecholamines as adrenalin, noradrenalin and dopamine like their organ counterpart, the chromaffin cells from the adrenal gland. Chromaffin cells and PC12 cells have been widely used for pharmacological and toxicological investigations of heavy metals (Weinsberg et al., 1995; Westerink and Vijverberg, 2002a), polychlorinated biphenyls (Messeri et al., 1997; Westerink and Vijverberg, 2002b) and alkaloids (Lee and Kim, 1996; Gafni et al., 1997; Bickmeyer et al., 1998; Kim et al., 2001; Smith et al., 2002). Hormone secretion is triggered by influx of extracellular calcium through voltage dependent calcium channels, which can be monitored using calcium sensitive dyes (Grynkiewicz et al., 1985; Deitmer and Schild, 2000). The 


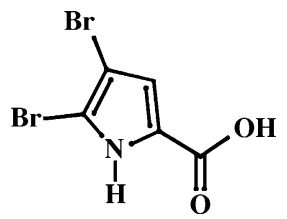

Fig. 1. Structure of 4,5-dibromopyrrole-2-carboxylic acid.

intracellular calcium level is crucial for numerous cellular processes as calcium is a ubiquitous second messenger following ligand binding of G-protein coupled receptors. Several plant alkaloids, for example cannabinoids (Khasabova et al., 2002) and tetrandrine (Bickmeyer et al., 1998) as well as caffeine (Bennett et al., 1998), affect calcium influx and calcium levels in neurons and secretory cells.

We decided to test one prominent bromopyrrole alkaloid, 4,5-dibromopyrrole-2-carboxylic acid (Fig. 1), for pharmacological effects on cellular signaling, focusing on intracellular $\mathrm{Ca}^{2+}$ signals in the well established cell line PC12.

\section{Material and methods}

\subsection{Culture methods}

PC12 cells from the DSMZ (German collection of microorganisms and cell cultures) were kept in culture medium containing RPMI 1640, 10\% fetal calf serum, 5\% horse serum, and 100 units penicillin/streptomycin per mL. Cells were cultivated in an incubator at $37^{\circ} \mathrm{C}, 90 \%$ humidity and $5 \% \mathrm{CO}_{2}$. Cells grew on collagen-coated cover slips and/or in collagen coated petri dishes. Cells were fed every three days and subcultivated when necessary.

\subsection{Fluorimetric measurements of intracellular calcium levels}

Cells were incubated with buffer (in mM: $125 \mathrm{NaCl}$, $2.5 \mathrm{KCl}, 1 \mathrm{MgCl}_{2}, 2 \mathrm{CaCl}_{2}, 1.3 \mathrm{NaH}_{2} \mathrm{PO}_{4}, 30$ glucose, 26 $N$-(2-hydroxyethyl)piperazine- $N^{\prime}$-2-ethanesulfonic acid $\mathrm{Na}$ salt (HEPES)) containing $5 \mu \mathrm{M}$ Fura II acetoxymethylester for $30 \mathrm{~min}$ at room temperature $\left(20 \pm 2{ }^{\circ} \mathrm{C}\right)$. The incubation buffer (with Fura II) was removed and cells were washed for 20 min (buffer without Fura II). Fluorescence of cells was monitored by an imaging system (Visitron, Puchheim) and a CCD camera mounted on an inverted microscope (Zeiss Axiovert 100). About 30 cells were measured simultaneously, separated using the region of interest function of the software. Fluorescence was obtained through an UV objective (Zeiss NeoFluar). Data were obtained by division of two images, one obtained at $340 \mathrm{~nm}$, the other at $380 \mathrm{~nm}$ excitation. For determination of R-min and R-max, 50 $\mu \mathrm{M}$ Fura II diluted in calcium buffer was used for R-max, buffer without $\mathrm{CaCl}_{2}$ but with additional $10 \mathrm{mM}$ EGTA for determination of R-min in calibration experiments. The Kd value of Fura II at room temperature was taken from the literature ( $135 \mathrm{nM}$; Grynkiewicz et al., 1985), the values of Sf2 and Sb2 were determined at $380 \mathrm{~nm}$ at calcium free and calcium saturated conditions obtaining a value $\mathrm{Sf} 2 / \mathrm{Sb} 2$ of 3.23 . Fluorescence ratios were converted into calcium concentrations by the formula given by Grynkiewicz et al., (1985). 4,5-Dibromopyrrole2-carboxylic acid was stored as $100 \mathrm{mM}$ stock solution in methanol at $4{ }^{\circ} \mathrm{C}$. The addition of less than $1 \%$ methanol (as vehicle control) to the experimental buffer did not change calcium signal of PC12 cells and 4,5-dibromopyrrole-2carboxylic acid did not interfere with Fura II in the concentration used in the experiments.

\subsection{Experimental design}

The recording chamber, mounted on a microscope had a volume of $2 \mathrm{~mL}$ and the peristaltic pump was adjusted to $3 \mathrm{~mL} / \mathrm{min}$ exchanging the chamber volume in less then a minute. To depolarize the cells, $80 \mathrm{mM} \mathrm{KCl}\left(\right.$ high $\mathrm{K}^{+}$) was used supplemented for $80 \mathrm{mM} \mathrm{NaCl}$ in the experimental buffer. The depolarization of the cellular membrane potential therefore increased gradually in less than a minute during perfusion. Cells were depolarized three times for 1 min during the course of a single experiment of about $60 \mathrm{~min}$. About 30 cells were measured simultaneously. By using a stock solution of $100 \mathrm{mM}$ 4,5-dibromopyrrole-2-carboxylic acid much lower concentrations than $1 \%$ methanol were applied in most experiments.

Results are presented as mean \pm S.E.M. Statistics and calculations were performed using computer software Prism (Graphpad) and Igor (WaveMetrics). The $t$-test ( $p<0.05$, two tailed) was used for calculations of significance. Drug induced changes of intracellular calcium elevation were compared with the corresponding controls $\left(1 . \mathrm{K}^{+}\right.$depolarization) with paired $t$-test. One experiment using around 30 cells was considered as $N=1$.

For analysis of the drug-induced delay, experiments were compared with a set of independent control experiments $(t$ test, unpaired). The spell to response $\left(1 . \mathrm{K}^{+}\right.$depolarization) was determined for each experiment and defined as zero delay, whereas the delay of $2 . \mathrm{K}^{+}$depolarization (with drug or as control) was reported.

\subsection{Isolation and extraction of 4,5-dibromopyrrole- 2-carboxylic acid}

The investigated brominated pyrrole alkaloid (Fig. 1) was isolated from dichloromethane/methanol extracts of Agelas wiedenmayeri and Agelas sventres using previously reported methods for isolation and structural elucidation (Assmann et al., 1999).

\section{Results}

PC12 cells responded to repetitive depolarizations without a change in the amplitude or time course of the calcium response (Fig. 2). 
A single experiment with simultaneous measurement of 30 cells $($ space bar $=$ SEM $)$

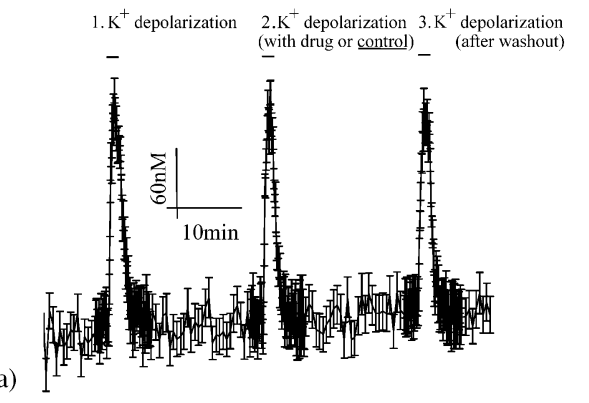

$2 . \mathrm{K}^{+}(\mathrm{control}) / 1 . \mathrm{K}^{+} \times 100$
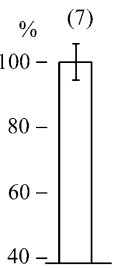

(a)

Onset of $\mathrm{Ca}^{2+}$ elevation during $\mathrm{K}^{+}$depolarization

(b)

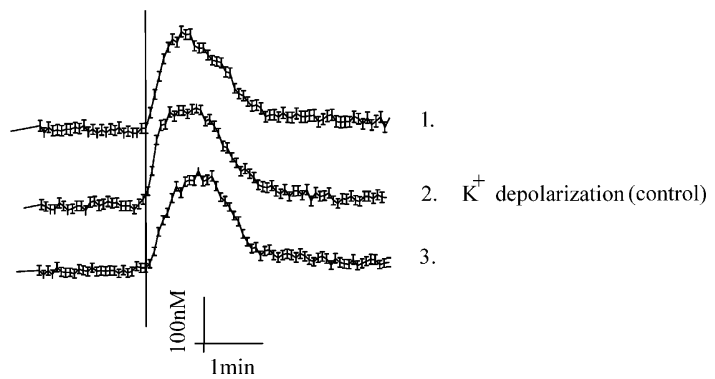

Fig. 2. (a) A typical experiment with three repetitive calcium elevations induced by $80 \mathrm{mM} \mathrm{K}^{+}$(control). The column shows the ratio $\times 100$ of the 2. $\mathrm{K}^{+}$depolarization to the $1 . \mathrm{K}^{+}$depolarization for seven different control experiments. (b) No delay of the onset of $\mathrm{K}^{+}$induced calcium elevations appears during repetitive stimulation.

The first $\mathrm{K}^{+}$depolarization was established as first control, which was normalized to $100 \%$, the second $\mathrm{K}^{+}$depolarization was under influence of the drug. The third $\mathrm{K}^{+}$depolarization was the washout control to reveal the reversibility of drug effects. The time between two $\mathrm{K}^{+}$depolarization was $20 \mathrm{~min}$.

\subsection{Delay of calcium elevation}

4,5-Dibromopyrrole-2-carboxylic acid delayed the onset of the calcium elevation induced by a $\mathrm{K}^{+}$depolarization (Fig. 3). This delay was at least partially reversible by washout of the drug for $20 \mathrm{~min}$. The maximum delay of calcium response induced by 4,5-dibromopyrrole-2-carboxylic acid was $23 \mathrm{~s}$ under the applied experimental conditions. Significant delays were obtained in a series of experiments using $30 \mu \mathrm{M} 4$,5-dibromopyrrole-2-carboxylic acid. However, in single experiments performed with 30 cells simultaneously, a reversible delay of calcium responses was observed at a concentration of $300 \mathrm{nM}$ 4,5-dibromopyrrole-2-carboxylic acid. During application of $300 \mu \mathrm{M}$ the delay was not significant, possibly by additional cellular effects of the substance at high concentrations counteracting the induced delay of calcium elevation. The delay can be correlated to the perfusion rate of the peristaltic pump to give additional $0.96 \mathrm{~mL}$ of the
Delay of $\mathrm{K}$ induced $\mathrm{Ca}$ elevation

by 4,5-Dibromopyrrole-2-carboxylic acid

Onset of $\mathrm{Ca}^{2+}$ elevation during $\mathrm{K}^{+}$depolarization $($space bar $=\mathrm{SEM}$ )

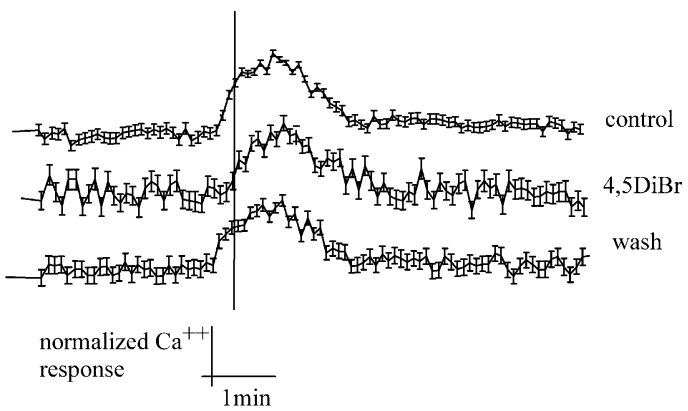

Delay of $2 . \mathrm{K}^{+}$depolarization in comparison the $1 . \mathrm{K}^{+}$depolarization

(b)

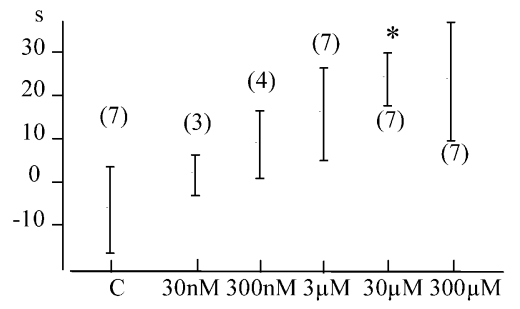

(c)

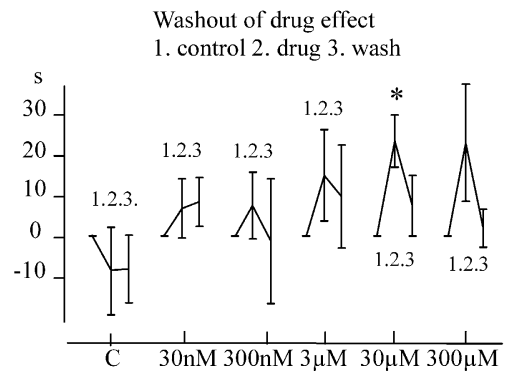

Fig. 3. (a) The onset of $\mathrm{K}^{+}$induced $\mathrm{Ca}^{2+}$ elevation is delayed by 4,5dibromopyrrole-2-carboxylic acid. (b) Dose dependent delay of calcium elevations. (*) $p<0.05$. (c) 4,5-Dibromopyrrole-2-carboxylic acid induced delay of calcium elevations is reversible by $20 \mathrm{~min}$ of washout. (*) $p<0.05$ between 2. depolarization of the controls (C) and 2. depolarization with drug $(30 \mu \mathrm{M})$. The cipher in ( ) represents the number of experiments $N$.

$\mathrm{K}^{+}$solution in the perfusion chamber to induce a calcium elevation.

\subsection{Reduction of calcium elevation}

4,5-Dibromopyrrole-2-carboxylic acid dose dependently reduced intracellular calcium elevations induced by $\mathrm{K}^{+}$ depolarization (Fig. 4). The reduction was visible after pre-incubation of the drug and was reversible by $20 \mathrm{~min}$ of washout. The highest concentration used was $1 \mathrm{mM}$ 4,5-dibromopyrrole-2-carboxylic acid. We refused to apply higher concentrations to prevent from more unspecific cellular effects of the sponge secondary metabolite. The lowest concentration used was $30 \mathrm{nM}$ whereas significant effects 


\section{Reduction of $\mathrm{K}^{+}$induced $\mathrm{Ca}$ elevation by \\ 4,5-Dibromopyrrole-2-carboxylic acid}

A single experiment with simultaneous measurement of 30 cells

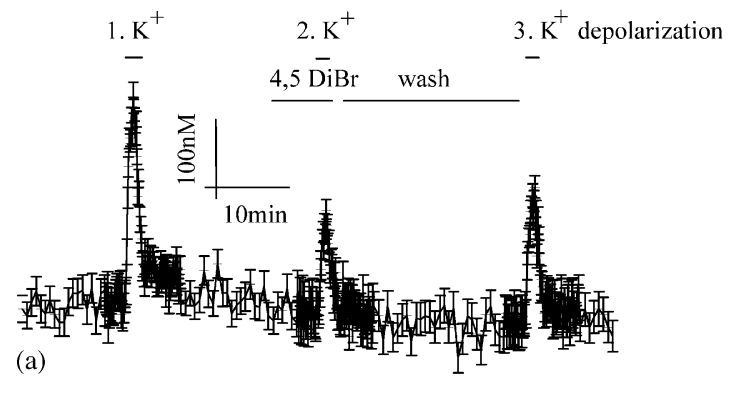

Normalized response to the $2 . \mathrm{K}^{+}$depolarization

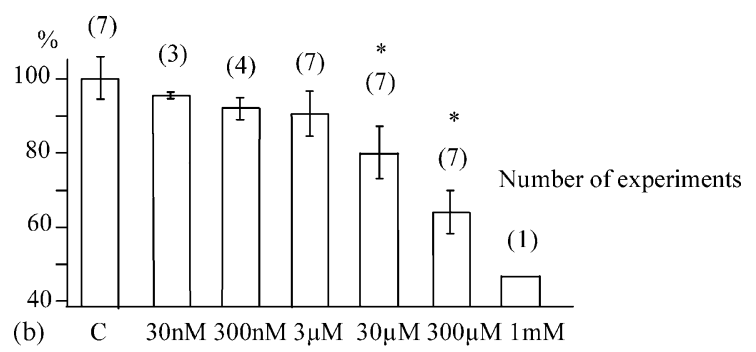

Washout of drug effect 1. control 2. drug 3. wash

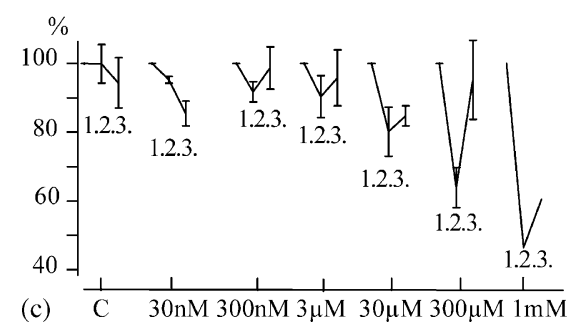

Fig. 4. (a) The $\mathrm{K}^{+}$induced $\mathrm{Ca}^{2+}$ elevation is reduced by 4,5-dibromopyrrole2-carboxylic acid. (b) Dose dependent reduction of $\mathrm{Ca}^{2+}$ elevations. $(*)$ $p<0.05$. (c) The reduction of the $\mathrm{Ca}^{2+}$ response is reversible by $20 \mathrm{~min}$ of washout. $(*) p<0.05$. The cipher in ( ) represents the number of experiments $N$.

were obtained using $30 \mu \mathrm{M}$ or more of 4,5-dibromopyrrole2 -carboxylic acid. However, at a concentration of $300 \mathrm{nM}$, we found a reversible reduction of calcium elevations in single experiments performed with about 30 cells simultaneously. 4,5-Dibromopyrrole-2-carboxylic acid without an additional depolarization did not induce an alteration of intracellular calcium levels. During depolarization, the majority of the intracellular calcium elevation is by calcium ions entering the cell via voltage dependent calcium channels. This calcium entry depolarizes the cell and accelerates the $\mathrm{K}^{+}$induced depolarization. A reduction of voltage gated calcium entry reduces the $\mathrm{K}^{+}$depolarization induced calcium elevation and delays the onset of intracellular calcium elevations as reported above.

\section{Discussion}

Many marine species in pelagic or benthic environments have few possibilities to hide or to flight from potential predators, therefore they developed chemical and physical defense strategies. Sponges are soft-bodied, sessile, and appear to be physically vulnerable to predation in an environment noted for intense grazing activity by fishes. One chance of survival is therefore to produce secondary metabolites to deter consumption by predatory fishes (e.g. Chanas et al., 1996; Wilson et al., 1999; Assmann et al., 2000; Kubanek et al., 2000; Assmann et al., 2004).

One example of these sponge secondary metabolites is 4,5-dibromopyrrole-2-carboxylic acid, which defends some Agelas species (A. clathrodes, A. cervicornis, A. dispar and A. wiedenmayeri) from common predatory reef fishes like Thalassoma bifasciatum (Chanas et al., 1996; Assmann et al., 2000, 2004). If such a deterrent comprises, beside its unpalatability to the fish, any pharmacological potency was only known in part for oroidin. Oroidin is also present within the tissues of A. clathrodes, A. cervicornis, A. dispar and A. wiedenmayeri (Braekman et al., 1992; Assmann et al., 1999, 2000; Lindel et al., 2000; Assmann et al., in press) and has previously been shown to be cytotoxic (König et al., 1998).

To investigate cellular effects of feeding deterrents was the original idea we followed in our experiments. Our results indicate, that the unpalatability of 4,5-dibromopyrrole2-carboxylic acid against predatory reef fish is not (only) transduced by specific membrane receptors present on sensory nerve cells but (additionally) on a more general pharmacological effect on the cellular calcium homeostasis, even in a rat phaeochromocytoma cell line. 4,5-Dibromopyrrole-2carboxylic acid itself did not alter the cellular calcium signals after addition to the bath solution. Its effect became visible during a depolarization of the cell membrane, which induces calcium entry via voltage operated calcium channels. The depolarization induced calcium elevation was reduced and delayed by 4,5 -dibromopyrrole-2-carboxylic acid. $\mathrm{Ca}^{2+}$ entry depolarizes the cell itself and accelerates the $\mathrm{K}^{+}$induced depolarization. Therefore, we favor voltage gated calcium channels to be a primary cellular target of 4,5-dibromopyrrole-2carboxylic acid. To develop its effect, a few minutes of preincubation with 4,5-dibromopyrrole-2-carboxylic acid was necessary. In the light of the obtained results concerning the delayed onset of the calcium elevation during $\mathrm{K}^{+}$depolarization, other scenarios of drug action may be possible. A slight depolarization of the cellular membrane potential may induce an inactivation of voltage activated calcium channels and only a remaining small fraction of channels (possibly high voltage activated channels) are gated by stronger membrane depolarization at higher $\mathrm{K}^{+}$levels. A blockade of a subset of voltage gated calcium channels would also match the drug effects reported in this work. To illuminate these problems another experimental approach could be employed. Electrophysiological techniques may deliver more information about ion channel effects of 4,5-dibromopyrrole-2-carboxylic acid and 
related brominated pyrrole alkaloids. This will be one of our future approaches to investigate the pharmacological properties of 4,5-dibromopyrrole-2-carboxylic acid in detail.

\section{Acknowledgements}

We would like to thank the students Kathrin Schröder (University of Lüneburg) and Christoph Drechsler (University of Hamburg) for excellent support during the experiments.

\section{References}

Assmann, M., Lichte, E., Soest, R.W.M.van, Köck, M., 1999. New bromopyrrole alkaloid from the marine sponge Agelas wiedenmayeri. Org. Lett. 1, 455-457.

Assmann, M., Lichte, E., Pawlik, J.R., Köck, M., 2000. Chemical defenses of the Caribbean sponges Agelas wiedenmayeri and Agelas conifera. Mar. Ecol. Prog. Ser. 207, 255-262.

Assmann, M., Lichte, E., Köck, M., 2004. Multiple defensive roles for bromopyrrole alkaloids from Caribbean Agelas sponges. Proceedings of the 6th International Sponge Symposium Boll. Mus. Ist. Biol. Genova $68,187-193$.

Bennett, D.L., Bootman, M.D., Berridge, M.J., Cheek, T.R., 1998. Ca ${ }^{(2+)}$ entry into PC12 cells initiated by ryanodine receptors or inositol 1,4,5trisphosphate receptors. Biochem. J. 329, 349-357.

Bickmeyer, U., Weinsberg, F., Muller, E., Wiegand, H., 1998. Blockade of voltage-operated calcium channels, increase in spontaneous catecholamine release and elevation of intracellular calcium levels in bovine chromaffin cells by the plant alkaloid tetrandrine. Naunyn Schmiedebergs Arch. Pharmacol. 357, 441-445.

Braekman, J.C., Daloze, D., Stoller, C., Soest, R.W.M.van, 1992. Chemotaxonomy of Agelas (Porifera: Demospongiae). Biochem. Syst. Ecol. 20, 417-431.

Chanas, B., Pawlik, J.R., Lindel, T., Fenical, W., 1996. Chemical defense of the Caribbean sponge Agelas clathrodes. J. Exp. Mar. Biol. Ecol. 208, 185-196.

Deitmer, J.W., Schild, D., 2000. Ca(2+) und pH Ionenmessungen in Zellen und Gewebe. Spektrum Akademischer Verlag, Heidelberg, Berlin.

Gafni, J., Munsch, J.A., Lam, T.H., Catlin, M.C., Costa, L.G., Molinski, T.F., Pessah, I.N., 1997. Xestospongins: potent membrane perme- able blockers of the inositol 1,4,5-trisphosphate receptor. Neuron 19, 23-33.

Grynkiewicz, G., Poenie, M., Tsien, R.Y., 1985. A new generation of $\mathrm{Ca}(2+)$ indicators with greatly improved fluorescence properties. J. Biol. Chem. 260, 3440-3450.

Khasabova, I.A., Simone, D.A., Seybold, V.S., 2002. Cannabinoids attenuate depolarization-dependent $\mathrm{Ca}(2+)$ influx in intermediate-size primary afferent neurons of adult rats. Neuroscience 115, 613-625.

Kim, S.H., Shin, J.S., Lee, J.J., Yin, S.Y., Kai, M., Lee, M.K., 2001. Effects of hydrastine derivatives on dopamine biosynthesis in PC12 cells. Planta Med. 67, 609-613.

Kubanek, J., Whalen, K.E., Engel, S., Kelly, S.R., Henkel, T.P., Fenical, W., Pawlik, J.R., 2000. Multiple defensive roles for triterpene glycosides from two Caribbean sponges. Oecologia 131, 125-136.

König, G.M., Wright, A.D., Linden, A., 1998. Antiplasmodial and cytotoxic metabolites from the Maltese sponge Agelas oroides. Planta Med. 64, 443-447.

Lee, M.K., Kim, H.S., 1996. Inhibitory effects of protoberberine alkaloids from the roots of Coptis japonica on catecholamine biosynthesis in PC12 cells. Planta Med. 62, 1-4.

Lindel, T., Hoffmann, H., Hochgürtel, M., Pawlik, J.R., 2000. Structureactivity relationship of inhibition of fish feeding by spongederived and synthetic pyrrole-imidazole alkaloids. J. Chem. Ecol. 26, 1477-1496.

Messeri, M.D., Bickmeyer, U., Weinsberg, F., Wiegand, H., 1997. Congener specific effects by polychlorinated biphenyls on catecholamine content and release in chromaffin cells. Arch. Toxicol. 71, 416-421.

Pawlik, J.R., Chanas, B., Toonen, R.J., Fenical, W., 1995. Defenses of Caribbean sponges against predatory reef fish I. Chemical deterrency. Mar. Ecol. Prog. Ser. 127, 183-194.

Smith, J.V., Burdick, A.J., Golik, P., Khan, I., Wallace, D., Luo, Y., 2002. Anti-apoptotic properties of Ginkgo biloba extract EGb 761 in differentiated PC12 cells. Cell Mol. Biol. 48, 699-707.

Weinsberg, F., Bickmeyer, U., Wiegand, H., 1995. Effects of inorganic mercury $(\mathrm{Hg} 2+)$ on calcium channel currents and catecholamine release from bovine chromaffin cells. Arch. Toxicol. 69, 191-196.

Westerink, R.H., Vijverberg, H.P., 2002a. Ca(2+)-independent vesicular catecholamine release in PC12 cells by nanomolar concentrations of $\mathrm{Pb}(2+)$. J. Neurochem. 80, 861-873.

Westerink, R.H., Vijverberg, H.P., 2002b. Vesicular catecholamine release from rat PC12 cells on acute and subchronic exposure to polychlorinated biphenyls. Toxicol. Appl. Pharmacol. 183, 153-159.

Wilson, D.M., Puyana, M., Fenical, W., Pawlik, J.R., 1999. Chemical defense of the Caribbean reef sponge Axinella corrugata against predatory fishes. J. Chem. Ecol. 25, 2811-2823. 